\title{
RICHARD BRADLEY'S ILLICIT EXCURSION INTO MEDICAL PRACTICE IN 1714
}

\author{
by
}

FRANK N. EGERTON III*

\section{INTRODUCTION}

The development of professional ethics, standards, practices, and safeguards for the physician in relation to society is as continuous a process as is the development of medicine itself. The Hippocratic Oath attests to the antiquity of the physician's concern for a responsible code of conduct, as the Hammurabi Code equally attests to the antiquity of society's demand that physicians bear the responsibility of reliable practice. ${ }^{1}$ The issues involved in medical ethics and standards will never be fully resolved as long as either medicine or society continue to change, and there is no prospect of either becoming static.

Two contemporary illustrations will show the on-going nature of the problems of medical ethics. The first is a question currently receiving international attention and publicity: what safeguards are necessary before a person is declared dead enough for his organs to be transplanted into a living patient? The other illustration does not presently, as far as I know, arouse much concern among physicians: that medical students carry out some aspects of medical practice on charity wards without the patients being informed that these men are as yet still students.

Both illustrations indicate, I think, that medical ethics and standards should be judged within their context. If and when a consensus is reached on the criteria of absolute death, the ethical dilemma will certainly be reduced, if not entirely resolved. If and when there is a favourable physician-patient ratio throughout the world and the economics of medical care cease to be a serious problem, then the relationship of medical students to charity patients may become subject to new consideration. In such ways, conditions influence ethics and standards.

Armed with this perspective, one will not judge those involved in medicine in the early years of the eighteenth century according to present-day criteria. That was a time when even the best physicians might do more harm than good for their patients; when apothecaries prescribed medicines as well as preparing them; when a medical degree from a British university was not a guarantee of first-hand medical experience; when charlatans and self-made practitioners were often tolerated or condoned by society; when there were not nearly enough physicians; when many members

\footnotetext{
- I wish to thank Gilman D. Grave, M.D., The National Institutes of Health, for reading this paper and providing many helpful suggestions, and Professor Edward O. Doughtie, Rice University, for checking several citations for me at the British Museum after my return from there.

1 Henry E. Sigerist, 'The history of medical licensure', J. Am. med. Ass., 1935, 104, 1056-60; reprinted by Milton I. Roemer, ed., Henry $E$. Sigerist on the Sociology of Medicine, New York, MD Publications, 1960, 308-18. Benjamin Spector, 'The growth of medicine and the letter of the law', Bull. Hist. Med., 1952, 26, 499-525. Richard Harrison Shryock, Medical Licensing in America, 1650-1965, Baltimore, Johns Hopkins University Press, 1967, ch. 1.
} 
of the Royal College of Physicians were more concerned with establishing an exclusive and profitable guild than they were in raising standards of practice; and when even the flimsy regulations governing medical practice in Britain applied primarily to London and its environs. ${ }^{2}$

\section{THE BACKGROUND OF BRADLEY'S EXPERIENCE}

The case of Richard Bradley (1688?-5 November 1732) practising medicine without having had any medical training was not unusual for the times, but it is noteworthy because Bradley was already a Fellow of the Royal Society and was later appointed the first Professor of Botany at Cambridge University. Furthermore, he was later to make significant contributions to biology. ${ }^{3}$ This case is also interesting because knowledge of it comes from candid private letters rather than from either the public proclamations of a quack or the complaints of physicians or society. As evident from his letters quoted below, Bradley apparently took the role of physician without premeditation because he was susceptible to the flattery of status, he needed money, and the opportunity arose from little effort on his part. Having assumed the role of physician, he did the best he could for the few patients he acquired.

Very little is known about Bradley's early years. He apparently came from a middle class family. He spent most of his adult life in and around London, and it is likely that he was born in that area. If 1688 is his birth date, he must have married before the age of 24, because he sent his blessing to his children in a letter dated 11 May O.S. 1714 , when he was presumably 26 years old.4 In one of his books he wrote that he had been interested in gardening since childhood, 5 but nothing definite is known about his education. Thomas Martyn (1735?-1825), whose father, John Martyn (1699-1768), succeeded Bradley as Professor of Botany at Cambridge University, wrote that 'Bradley was never of any university, and had no education . . . . Anything that either of the Martyns said about Bradley is suspect, because John Martyn was jealous of Bradley's professorship and maliciously denigrated both him

' Lester S. King, The Medical World of the Eighteenth Century, Chicago, University of Chicago Press, 1958. George Clark, A History of the Royal College of Physicians of London, Oxford, Clarendon Press, 1966, vol. 2, chs. 22-27. Cecil Wall, A History of the Worshipful Society of Apothecaries of London 1617-1815, ed. by $\mathbf{H}$. Charles Cameron, revised by E. Ashworth Underwood, London, New York, Toronto, Oxford University Press for The Wellcome Historical Medical Museum, 1963. Gordon D. Rowley, 'Introduction', in Richard Bradley, Collected writings on Succulent Plants, London, Gregg Press, 1964, vii-xxiv. Frank N. Egerton, 'Richard Bradley's understanding of biological productivity: a study of 18th century ecological ideas', J. Hist. Biol., 1969, 2, 391-410. Frank N. Egerton, 'Richard Bradley's relationship with Sir Hans Sloane', Notes Rec. R. Soc. Lond., 1970,5 , in press.

His birth year is given as 1688 by Donald McDonald, Agricultural Writers, from Sir Walter of Henley to Authur Young, 1200-1800 .... London, Horace Cox, 1908, 170. The Bradley letters are in the Sloane Manuscripts of the British Museum. Cf. Sloane 3322 fol. 50. The Gregorian Calendar replaced the Julian Calendar throughout Holland by 1700, but not in Britain until 1752 . While in Holland Bradley dated his letters either O.S. (Old Style) or N.S. (New Style), indicating respectively the calendars used in Britain and Holland. To minimize confusion, his dating is preserved here. To convert from Old to New Style, add 11 days to the Old Style date.

Bradley, New Improvements of Planting and Gardening, both Philosophical and Practical; explaining the motion of sap and generation of plants; with other discoveries . . ., 3rd ed., 3 pts., London, W. Mears, 1719-20, [viii].

- Letter from Thomas Martyn to James Edward Smith, dated 12 April 1818, published by Lady Smith in Memoir and Correspondence of the late Sir James Edward Smith, M.D., 2 vols., London, Longman, 1832, vol. 2, p. 387. 


\section{Richard Bradley's Illicit Excursion into Medical Practice in 1714}

and others; ${ }^{7}$ but it is probably true that Bradley attended no university. His writings attest to his having received a fairly good education, but he probably was not an outstanding student; had he been, he might have been granted a university fellowship. Although he wanted to be neither gardener nor farmer, plants remained a dominant interest throughout his life. The main reasons for studying plants at that time were either medicinal or agricultural, but Bradley was one of a growing number of people who were interested in plants primarily for aesthetic and scientific reasons. He probably became a member of the informal Temple Coffee House Botany Club that seems to have orignated in 1689 and persisted until $1717 .^{8}$

It may have been through this group that he met the affluent apothecary, James Petiver (c. 1663-20 April 1718), who became his mentor. Petiver, a bachelor, was an insatiable collector of res naturae. He was the one most likely responsible for getting Bradley into the Royal Society, which favour was probably granted in hopes that Bradley would repay it by adding to Petiver's collections. This possibility is suggested by the fact that Petiver got Patrick Blair(1666?-1728) into the Royal Society on the date Bradley joined (1 December 1712), after Blair had added to Petiver's collections.'

In 1714 Bradley went to Holland to obtain biological specimens for himself, Petiver, and others. It is from the letters written during this trip that we gain an insight into Bradley's practice of medicine. ${ }^{10}$ On this trip he followed in the footsteps of Petiver, who had gone there as the agent of another collector, Dr.Hans Sloane. The contacts Petiver made in 1711 were to be useful to Bradley three years later. In Leiden Petiver made the acquaintance of Dr. Herman Boerhaave (1668-1738), who probably was the one who persuaded the University to confer upon Petiver a Doctor of Medicine degree. ${ }^{11}$ In Amsterdam Petiver met Dr. Frederik Ruysch (1638-1731), Professor of Anatomy and Botany, and Dr. Caspar Commelin (16671731), Professor of Botany at the Athenaeum and Director of the Hortus Medicus.

Although it seems that Bradley began his medical practice because he succumbed to the temptation of an unpremeditated set of circumstances, there is evidence of an earlier bent for clandestine behaviour. Perhaps he was already in trouble with creditors before he left London, for in a note written in April, apparently to Petiver, he requested: 'do me the favour to come \& meet me at the 2 Fighting Cocks in St. George's

\footnotetext{
' Raymond Williamson, 'John Martyn and the Grub-street Journal, with particular reference to his attacks on Richard Bentley, Richard Bradley and William Cheselden', Med. Hist., 1961, 5, 361-74. George Cornelius Gorham, Memoirs of John Martyn, F.R.S., and of Thomas Martyn, B.D., F.R.S., F.L.S., Professors of Botany in the University of Cambridge, London, Hatchard, 1830, 31-33.

- This club has been described by George Pasti, Jr., Consul Sherard: Amateur Botanist and Patron of Learning, 1659-1728, Ph.D dissertation, University of Illinois, Urbana, 1950, 48-55, 190-91.

- Letters from Petiver to Blair, dated 22 June 1712 and 29 January 1712/3. Sloane 3338 fols. 85, 135-36. On Petiver, see Raymond Phineas Stearns, 'James Petiver, promoter of natural science', Proc. Am. antiquarian Soc., 1953, 62, 243-365. George Simonds Boulger, 'Petiver, James (1663-1718)', Dict. Nat. Biog. J. E. Dandy and James Britten, The Sloane Herbarium. An annotated list of the horti sicci composing it; with biographical accounts of the principal contributors, London, British Museum, 1958, 175-82.

${ }_{10}$ Most of the discussion in these letters concerns natural history. I plan to discuss this aspect of Bradley's trip in a later article.

11 Awarded 28 July 1711. The Leyden Album gives his age as 45. Robert William Innes Smith, English-speaking Students of Medicine at the University of Leyden, Edinburgh, London, Oliver \& Boyd, 1932, 181. I am indebted to Dr. Emily Emmart Trueblood for checking this reference. Cf. also the congratulatory letter from Patrick Blair to Petiver dated 27 August [O.S.] 1713. Sloane 3321 fol. 284.
} 


\section{Frank N. Egerton III}

Fields, because I want to talk with you a little this afternoon. But mention nothing at that place of my design for [going to] Holland. ${ }^{12}$ However, there is some indication (in the next two letters) that Bradley's clandestine behaviour might have arisen to meet a psychological rather than a situational need. It may have been a game which satisfied a desire to disappear in order to become someone else, someone more successful than Richard Bradley.

The first day of his journey, 1 May O.S., he travelled from London to Colchester, where he presented a letter of introduction from Petiver to a Mr. John Luftkin. Bradley stayed there three days to see oyster pits and other natural 'curiosities'.13 After he left, Luftkin wrote to Petiver: 'On Friday last I hope you received a box and a paper parcel by our Chelsea Coach, remitted to me for the purpose by your friend, which you recommended to me, Mr. Geo. Grant, alias Mr. Rich. Bradley, who on Saturday morning last set sail ... for the Batavian coast, where I doubt not, but that he is safely arrived, clear of all danger.'14 Bradley signed a letter to Petiver dated 5 May O.S. with the alias George Grant, ${ }^{15}$ and on 11 May O.S. he wrote that at Harwich 'one Mr. Grant, a person in a black wig, was invited to dinner with the candidates for Parliament [and he] was entertained with roasted Westphalia ham and the compliment of being like his brother, the oculist.'16

In this passage Bradley revelled in his successful masquerade. He did not indicate any thoughts of pretending to be a physician, but it is noteworthy that he claimed to be the brother of the oculist whose name was Roger Grant, and who had passed through the professions of cobbler and Anabaptist preacher before becoming a quack eye specialist. Bradley's willingness to be related to him was probably because Roger Grant had found favour with Queen Anne (1655-1 August 1714). However, not everyone was as blind as the queen to his charlatism, for he inspired the writing of two satiric poems. One of them neatly portrayed his life in six lines:
A tinker first his scene of life began;
That failing, he set up for cunning man;
But wanting luck, puts on a new disguise
And now pretends that he can mend your eyes,
But this expect, that, like a tinker true,
Where he repairs one eye he puts out two. ${ }^{17}$

18 Sloane 4058 fol. 51, dated 27 [?] April. The year is not given, but the contents indicates 1714. In the quotations from Bradley's letters, spellings, capitalizations, and punctuation have sometimes been modernized. Editorial additions are placed in square brackets.

13 Sloane 3322 fol. 49, dated 11 May O.S., sent from Leiden and received by Petiver in London on 15 May O.S.

14 Sloane 4065 fol. 161, dated 11 [?] May [O.S.]

16 Sloane 4065 fol. 160 , sent from Harwich.

16 Sloane 3322 fol. 49 . In his reply, Petiver stated that he had shown Bradley's letter to Sloane. Sloane 3340 fol. 23. dated 15 [?] May O.S. It seems unlikely that he showed the later Bradjey letters to Sloane, but after Petiver's death in 1718, Sloane acquired the correspondence. Whether he then read Bradley's other letters to Petiver is unknown.

17 Quoted in J. Cordy Jeaffreson, A Book about Doctors, London, Hurst \& Blackett, 1860; quoted from American ed., New York, Rudd \& Carleton, 1861, 99. On Roger Grant, see Richard Steele, The Spectator, no. 444 (30 July 1712) and no. 472 (1 September 1712) and notes by Donald F. Bond, ed., The Spectator, Oxford, Clarendon Press, 1965, 4, 61, 173. Eric Jameson, The Natural History of Quackery, Springfield, IIl., Charles C. Thomas, 1961, 81. Charles John Samuel Thompson, The Quacks of Old London, London, New York, Paris, Brentano's, 1928, 280-82. 
EXPERIENCES IN HOLLAND

The day Bradley arrived in Holland, 9 May O.S., he visited Antoni van Leeuwenhoek (1632-1723). ${ }^{18} \mathrm{He}$ must have had a letter of introduction from Petiver, because without one he probably would not have been admitted. Petiver himself had been turned away on 2 August 1711, though Leeuwenhoek later wrote him an apology:

... if you had kept by you the letter from Mr. Hans Sloane, you would not have missed a friendly entertainment at my house. And you were sent away especially because you were not known, and because some 8 or 10 days earlier no less than 26 people came to see me within four days, all of them with introductions (except a Duke and a Count, with their Tutor): which made me so tired, that I broke out in a sweat all over. This being so, I beg that you will not take it amiss in me, that, to my great sorrow, you were turned away. ${ }^{10}$

Bradley promised to describe Leeuwenhoek's 'rarities' in his next letter, but he later failed to do so.

Bradley's letter of 20 June N.S. opened playfully: 'The Great Grant to his loving Friend Sends Greeting.' He then proceeded to describe his initial reactions to the physicians to whom he had letters of introduction from Petiver. Boerhaave had been made Professor of Botany and Medicine in 1709, he had published a catalogue of the Leiden botanical garden in 1710, and he had become Rector of the University by February $1714 .{ }^{20} \mathrm{He}$ was a prominent and busy professor when Bradley met him, but Bradley, who was himself only a neophyte botanist, obviously felt that his reception was not cordial enough:

I made my first address of Dr. Boerhaave, who with much civility received me \& gave me recommendation to a good ordinary [in which] to dine. Afterwards he was my humble servant in the Garden, where I feasted on novelties with much satisfaction. I compassed some rare plants at that place \& his new catalogue, which is just published. He is in high esteem for anatomy \& medicine. I was there 4 days \& at my departure got a glass of wine out of him. His collection of shells is fine. He is civil in his way, but not like Dr. Ruysch."21

It seems that his visit made no lasting impression on Boerhaave, because in 1720 he wrote to William Sherard and asked about Bradley. The inquiry carried no indication of any personal recollection: 'Do you know Mr. Bradley? I have heard that he is a very wise botanist \& very expert in cultivation. ${ }^{22}$

In Amsterdam Bradley met with a warm reception, and he stayed there for the major part of his journey. His first experiences were ecstatic:

18 Sloane 3322 fol. 50.

10 Dated 18 August 1711. Trans. by Clifford Dobell, Antony van Leeuwenhoek and his Little Animals': being some account of the father of protozoology \& bacteriology and his multifarious discoveries in these disciplines, 1932; quoted from 2nd ed., New York, Russell and Russell, 1958, 79. Another trans. also exists, Sloane 3338 fol. 8, quoted by Stearns, Petiver, p. 284.

so G. A. Lindeboom, Herman Boerhaave, the Man and his Work, London, Methuen, 1968.

"Sloane 3322 fol. 52. This letter which opened with greetings from 'The Great Grant' closed with the signature 'R. Bradley'.

s2 'Connoissez Vous Monsr. Bradley? on me dit, q'il sint tres scavant Botanist, \& tres expert dans la culture'. Dated 10 September 1720. G. A. Lindeboom, ed., Analecta Boerhaaviana, vol. 3: Boerhaave's Correspondence, part one. Leiden, E. J. Brill, 1962, 92. In the next letter to Sherard, dated 27 December 1720, Beorhaave wrote: 'I already know your Bradley of whom Mr. Rand has told me true things. A very prominent British gentleman stayed here at Leyden to recover his health; when I conversed with him on account of my medical profession, I heard much concerning the excellence of this man in botany, especially about a successful and particular way of cultivation; this had as result that I endeavoured to discover who he might be.' Trans. by Lindeboom from Latin. Ibid., 95. 


\section{Frank N. Egerton III}

'Tis with difficulty (notwithstanding my great skill in opticks) that I have hitherto preserved my eyesight - the darling beauties of those cabinets $I$ have seen are sufficient to blind the World. Dr. Ruysch has with a pure English good nature given me several fine things, \& by his repeated favours I am still in expectation of more. His son is likewise as hearty, \& I am not only in expectation of sharing his collection, but also of some others he addresses me to. Dr. Commelin has generously given me full commission to take what I think proper from the Garden (from the Nettle to the Coffee tree), \& I am now making the best use of my time in drying all the plants of that curious place. 23

His cordial reception was probably attributable in part to the eagerness of Ruysch, and to some extent Commelin and others, to exchange biological specimens with Petiver, Sloane, and other Englishmen.

Since botanical gardens were most often maintained for growing medicinal plants, it was easy to assume that the alert young Englishman who busied himself in the Hortus Medicus, and who enjoyed the hospitality of Drs. Ruysch and Commelin, was a physician. Bradley apparently did not originate the deception, but, like Sganarelle, he obviously enjoyed it:

The people here will have me a Doctor whether I will or no, $\&$ to carry on the jest I desire you will favour me with the recipe of some medicines for the venereal distemper. For here are some English gentlemen who now and then receive that favour \& won't be persuaded to take Dutch pills. I know a little of the method [to use] where it is but beginning, as the Salts [and] Lenitive Electuary. I want the recipe of Camphor pills ... . ${ }^{24}$

Bradley's letters give the impression that he played along with this mistaken assumption about his profession because he was flattered by the feeling of importance it gave him. However, this motive was reinforced by his financial difficulties. By 20 June N.S. he mentioned this problem to Petiver: 'when you go towards Fountain Court you will please to mention the name of Rhino, for till I have that I cannot send over the plants or other curiosities.' ${ }^{25}$ Similar pleas followed in other letters. Since his money did not arrive when he needed it, it occurred to Bradley that he could alleviate his predicament by collecting medical fees. But that feelings of power and status were prime motive is evident:

I have had the good fortune to show several English gentlemen the Garden. One of them is gone for England \& will wait on you with desire to see Dr. Sloane's curiosities \& those of our Museum. His name is Bailie, ${ }^{26}$ a student of physick at Leyden. He drank coffee with the Dr. in the black wig \& has a letter from me to recommend him to your favour. We drank your health in coffee. Pray carry on the jest, for 'tis like to prove a good one. For Dr. Ruysch teaches me anatomy, \& with my own Smatch of botany, I begin to smell a little Quackish. And let me tell you, the very mountebanks here wear embroidered coats \& full bottomed perukes, \& I now only want to have seen the courts of Europe to be at least equal with them. Besides, as I am a stranger here, novelty pleads a little for me. ${ }^{27}$

23 Sloane 3322 fol. 52.

${ }^{24}$ Sloane 3322 fol. 59 . Dated 4 July N.S. Received by Petiver 25 June O.S. The similarity of attitude between Bradley and Sganarelle in the play by Molière, Le médecin malgré lui, was called to my attention by Miss Nancy C. Waldum, to whom I extend my thanks. On the preparation of lenetive electuary, see the appendix.

${ }^{25}$ Sloane 3322 fol. 53.

26 Probably Robert Baillie, from Scotland, who received his medical degree from Leiden at age 23, on 6 October 1713; it is possible, however, that the student was either Edward or George Bailey, brothers from Havant, England, who received their degrees from Leiden on 16 September 1715 . Cf. Smith, English-speaking Students of Medicine at the University of Leyden, 11.

37 Sloane 3322 fol. 61 . Dated 24 [July] N.S. Received by Petiver 17 July O.S. In the same tone, Bradley wrote for another acquaintance from Holland a letter of introduction to Petiver. Sloane 4058 fol. 55. Dated 1 September N.S. 


\section{Richard Bradley's Illicit Excursion into Medical Practice in 1714}

Nor were Bradley and the mountebanks the only ones travelling incognito. He reported that the King of Prussia (Frederick William I) had spent three days in Amsterdam under the guise of a count, and 'I was in his company with some officers and did not know it till it was too late.'28

Since Petiver was prominent in both scientific and medical circles, one might expect him to have cautioned Bradley, in a fatherly fashion, against the irresponsibility of treating patients without adequate training and advised him of the folly of so lightly jeopardizing his reputation. But Petiver did just the opposite. Apothecaries at that time were asserting that medical training was not a necessary prerequisite for prescribing medicines. Furthermore, there was still current an old tradition of physicians writing prescriptions and instructions for medical care in absentia. ${ }^{29}$ These situations must have influenced Petiver's thinking. He may also have believed that Bradley was picking up enough knowledge from his association with Dr. Ruysch to qualify as a physician, just as he himself had become an apothecary through apprenticeship. Furthermore, he may have liked the idea of Bradley's helping to pay for his trip by collecting medical fees, thereby relieving Petiver of some of the responsibility.

Whatever Petiver's motives were, he obliged Bradley by sending him advice and recipes for medicines. In Bradley's letter dated 31 July [N.S.], he informed Petiver that his letter had arrived with Bradley's doctoral degree. Was there any legitimate way in which Petiver could have obtained one for him? Not very likely. This is undoubtedly another sample of Bradley's coy irony. His letter continued:

\footnotetext{
I have two patients, \& [they] take upon me at a huge rate. I have learned to write the recipes by heart, but you have forgot that for the diet drink made of Sassafras, Guaiacum, Sarsaparilla, \&c., which I hope will come in your next [letter], with some recipes for a fever or other common distemper. Likewise [I want to know] how to take away a swelling in the testicles, and a cataplasm to raise buboes when they begin to appear, with what caustic to apply when it is come to a head, \&c. ${ }^{.0}$
}

One of his patients had taken him to visit The Hague, had treated him nobly, and would probably pay him well for his services. In closing, Bradley advised Petiver of his new persona: 'The cant to be observed by my friends in England: a Doctor in Physick, bred at Oxford, in a black periwig, a great Virtuoso, \& now traveling for the Improvement of Natural Knowledge.'

Petiver's reply, dated 3 Aungust O.S., contained the requested recipe for the medicine and advice about treatments. ${ }^{31}$

Although Bradley tried to be a good physician, he did not seem to suffer from any anxiety should he fail. His next letter shows that he viewed his medical practice partly as a game.

I have had a patient who about two [ten?] months ago got a mishap. I followed the prescribed method, but the Camphor pills, only three in a day, made him piss almost every minute, $\&$ with the greatest pain, so that he was quite broken hearted. And that which was worse, as soon as

28 Sloane 3322 fol. 61 .

30 King, Medical World of the Eighteenth Century, ch. 1.

so Sloane 3322 fol. 63.

21 Sloane 3340 fol. 6-7. 


\section{Frank N. Egerton III}

he had gotten a little relief from them, a violent Cholick seized him, which I have cooked up for two days, \& he is almost recovered.

It would make you laugh if you had seen my grave way of managing him \& how much the good opinion [had] of the physician works the cure. There was: 'Dear Dr., stay with me, for I am half dead when you leave me.' 'Drink what you will, you are welcome.' 'Pray, call for a flask of Burgundy, \& I will assure you I will make it worth your while if [you] will but tarry a little while by me.' \&rc. Thus have I been treated by him, \& [I] hope to find some benefit in my pocket.

I, on my side, when I don't know what to do, say I am not for giving more Physick than is absolutely necessary, \& as I find nature has yet strength enough to help itself, I recommend a little patience \& all will be well. And to make up for all, I attend 6 times a day \& receive the thanks of the whole house for my great care \& wise conduct. However, as yet I own to you I have not capacity enough to write a bill for a Cordiale Julape, or give a common purge, or know the quantity of the Ipecacuanha root for an emetick, or what quant[ity] of Anodynes. You may judge of the state of Physick in Holland when the first physician writes after this manner. Your next [letter], I hope, will mend [these] errors. ${ }^{22}$

The technique of writing a prescription was difficult for Bradley. He requested Petiver to send him 'the marks with their signification that are used in the weight \& measure in Physick, as a Drachm, 1/2 a Drachm, \&c., \& what quantity of the Cortex for Intermitting fevers.' But then it occurred to him that he could find some of the answers for himself, and he answered one of his own questions: ' $I$ have this moment looked into Dr. Sydenham \& find the quantities \& how to write for it.' ${ }^{33}$ But even then he found it difficult to write a plausible prescription, and later he confessed that he was 'not master of any mark but that for an Ounce, so that where a Drachm would do, the patient must be content to follow the Dr.'s rule \& buy a large quantity to have it always by them. ${ }^{34}$

These practices had not damaged his self-respect. This is evident from the following incident. When the plants for exchange arrived from London, he could not at first get them off the boat because he did not have enough money to buy the shipper a glass of wine. Bradley appealed to two burghermasters who intervened and had the plants unloaded. From this episode Bradley drew a moral. 'Thus, you see, a man may have honour without money, though he starve at the same rate. ${ }^{35}$

There is irony in his statement about honour, but he also experienced another kind of irony of which he was equally unaware. He wrote on 14 September N.S. that he had taken sick with the ague, but that he had the advice of the best doctor. This letter has partially faded, but the essence of this passage is clear: 'I find it something uneasy to be sick \& . . . I have advice enough from the best Dr. to eat . . . sugar till my guts crack, \& sometimes . . . change of diet. I shall make use of the bar . . . with Ipecacuanha. ${ }^{36}$ The reference to the best doctor may, or may not, have been to himself, but in a subsequent letter, dated 24 October N.S., he wrote that he had cured himself, his landlord, and his landlady with a drink he had invented. It consisted of a quart of water boiled with cinnamon, a quart of white wine, two lemons, and sugar-mixed and served hot. ${ }^{37}$ Thus, Bradley came to believe in his own curative

22 Sloane 3322 fols. 66-67. Dated 10 [20?] August O.S. On camphor and ipecacuanha, see the appendix.

I3 Sloane 3322 fol. 73. Dated 14 September N.S. Received by Petiver 7 September O.S. By 'Cortex for Intermitting fevers', Bradley undoubtedly meant Cortex Peruviana, the bark of Cinchona officianalis $L$., which was the source of quinine, introduced into Europe in the 1640s.

i Sloane 3322 fol. 79. Dated 24 October N.S.

as Sloane 3322 fol. 67.

"1 Sloane 3322 fol. 79. 
Richard Bradley's Illicit Excursion into Medical Practice in 1714

powers after having practised medicine sporadically for a little less than four months.

EPILOGUE

Bradley did not intend to continue his frivolous practising of medicine indefinitely. At the end of the summer he decided to go to Paris, 'and there study medicine in good ernest. '38 Unfortunately, this was an unrealistic hope. He had barely managed to support himself while exchanging biological specimens between collectors in Amsterdam and London. Having a family but no independent income, he could not have supported himself while a student in Paris.

There is no known evidence that when Bradley returned to London around the end of October N.S. that he attempted to continue his medical practice. It would have been very foolish for him to have done so where he was well known. It might have been possible for him to have obtained a medical degree from a Scottish university without much trouble, but it is doubtful that he tried. His interest was probably stronger in natural history than in medicine. He did persist a while longer in signing letters to Petiver with his pseudonym, Grant, ${ }^{\infty 9}$ but his last extant letters to Petiver were signed with either his real name or his initials. ${ }^{40}$ Petiver continued to flatter his friend by addressing him as 'Dr. Bradley'."1 When Bradley took a second wife, he must have told her he was a physician, because after his death she referred to him as 'Dr. Richard Bradley' in a petition for financial assistance she sent to Sir Hans Sloane. ${ }^{22}$

Both Bradley and Petiver acted irresponsibly in this episode, but at the time their behaviour would not have seemed very serious in comparison with the common and flagrant malpractices of both legitimate and illegitimate practitioners.

\section{APPENDIX: THE MEDICINES BRADLEY USED}

Except for the 'cortex for Intermitting fevers' (quinine) which could be used for treating malaria, it is doubtful that the recipes Bradley requested from Petiver would have helped his patients. The other substances he used were partly inert metabolically, partly food materials, and partly substances that cause physiological reactions. But the reactions from the last were not necessarily of benefit to the patient. For example, the root of ipecacuanha (Cephaëlis ipecacuanha (Stokes) Baill.) is indeed an emetic and is still listed in pharmacopoeias as such, ${ }^{43}$ but in the eighteenth century the use of emetics as a medicinal treatment was far greater than it should have been. Similarly, camphor pills, made from the bark of the camphor tree (Cinnamomum camphora (L.) T. Nees \& Eberm.), contains a stimulant, but even today there is uncertainty about how or when to use it. 4

Sloane 3322 fol. 73.

so Sloane 3322 fol. 84. Dated 13 March [O.S., 1715] and Sloane 4065 fol. 211. Dated 2 April [O.S.] 1715.

40 Sloane 3322 fols. 155, 156, 87. Dated 17 June, 4 July, 1 September [O.S.] 1715. Only the first of these has an address, but the contents of the other two indicate that they were all to Petiver.

11 Sloane 3340. Dated 23 November [O.S.] 1714.

is Sloane 4058 fol. 50. Apparently written in December 1732.

4 Arthur Osol, Robertson Pratt, and Mark D. Altschule, eds., The United States Dispensatory and Physicians' Pharmacology, 26th ed., Philadelphia and Toronto, J. B. Lippincott, 1967, 621.

u 'Systemically camphor stimulates the central nervous system; in sufficient doses it produces active convulsions. Experiments on the cardiovascular actions of camphor have been quite voluminous, but with extraordinary divergence of results.' Ibid., 234. 


\section{Frank N. Egerton III}

Since most of the medicines were worthless and those with active ingredients were used inappropriately, there is little to be gained from systematically describing and evaluating those that Bradley mentioned. However, it is interesting to read the recipe for just one of them in order to see that pharmacology, simple though it was according to modern standards, was too elaborate to be learned as casually as he hoped. All the medicines he mentioned were not as complex as lenetive electuary, but that one is representative of those in the pharmacopoeias of the seventeenth and eighteenth centuries. Since Petiver's letters are not entirely legible, the following recipe for lenetive electuary is quoted from the Pharmacopoeia Londinensis (1st ed., 1618, p. 116), translated by Nicholas Culpeper in 1649 and reprinted many times:

Take of Raisons of the Sun stoned, Polypodium of the Oak, Senna, of each two ounces. Mercury one handful and an half. Jujubes, Sebestens of each twenty. Maiden-hair, Violets, French Barley, of each one handful. Damsk Prunes stoned, Tamerinds of each six drams. Liquoris half an ounce. Boil them in ten pound of Water till two parts of the three be consumed; strain it, and dissolve in the Decoction Pulp of Cassia, Tamarinds, and Fresh Prunes, Sugar of Violets, of each six ounces. Sugar two pound. At last add powder of Senna leaves, one ounce and an half, Annis seeds in powder two drams to each pound of Electuary. And so bring it into the form of an Electuary according to art.cs

es Nicholas Culpeper, Pharmacopoeia Londinensis: or, the London dispensatory, further adorned by the studies and collections of the fellows, now living of the said Colledg. Being that book by which all apothecaries are bound to make up all the medicines in their shops ...., new ed., ed. by Abdiah Cole et al., London, Peter Cole and Edward Cole, 1661, 150. 1718 ed., London, W. Churchill, 216. 